12-1-2007

\title{
How Are Nonnative-English-Speaking Teachers Perceived by Young Learners?
}

Yuko G. Butler

University of Pennsylvania, ybutler@gse.upenn.edu

Follow this and additional works at: https://repository.upenn.edu/gse_pubs

Part of the Education Commons

\section{Recommended Citation}

Butler, Y. G. (2007). How Are Nonnative-English-Speaking Teachers Perceived by Young Learners?.

Retrieved from https://repository.upenn.edu/gse_pubs/188

Copyright $\odot$ Teachers of English to Speakers of Other Languages, Inc. (TESOL). Postprint version. This article may not be an exact replica of the final version published by TESOL. It is not the copy of record. Published in TESOL, Volume 41, Issue 4, December 2007, pages 731-755.

Publisher URL: http://www.tesol.org

This paper is posted at ScholarlyCommons. https://repository.upenn.edu/gse_pubs/188

For more information, please contact repository@pobox.upenn.edu. 


\title{
How Are Nonnative-English-Speaking Teachers Perceived by Young Learners?
}

\begin{abstract}
The current study examined the effects of Korean elementary school teachers' accents on their students' listening comprehension. It also examined students' attitudes toward teachers with American-accented English (a native speaker model) and Korean-accented English (a nonnative speaker model). A matchedguised technique was used. A Korean American individual recorded texts in both American-accented English and Korean-accented English. The study randomly assigned 312 Grade 6 Korean students to listen to one of these two recorded oral texts and their comprehension was examined. Next, all of the students listened to both accented-English tapes and their attitudes toward the two speakers (which were in fact the same speaker) were examined. Although the popular belief appears to assume that nonnative accented English would produce a negative effect on students' oral skills, the results failed to find any differences in student performance in terms of comprehension. However, the Korean children thought that the American-accented English guise had better pronunciation, was relatively more confident in her use of English, would focus more on fluency than on accuracy, and would use less Korean in the English class. The students also expressed a preference to have the American-accented English guise as their English teacher.
\end{abstract}

\section{Disciplines}

Education

\section{Comments}

Copyright $\odot$ Teachers of English to Speakers of Other Languages, Inc. (TESOL). Postprint version. This article may not be an exact replica of the final version published by TESOL. It is not the copy of record. Published in TESOL, Volume 41, Issue 4, December 2007, pages 731-755.

Publisher URL: http://www.tesol.org 
Publisher: misc; Journal: tesol:TESOL Quarterly

Job\#: 154732; Volume: 41; Issue: 4; Art\#: 41-4-04; Prod\#: 41-4-04;

Month: December; Year: 2007; Section Head: .

\title{
How Are Nonnative-English-Speaking Teachers Perceived by Young Learners?
}

\author{
PERCEPTIONS OF NONNATIVE TEACHERS
}

\section{YUKO GOTO BUTLER}

University of Pennsylvania

Philadelphia, Pennsylvania, United States

The current study examined the effects of Korean elementary school teachers' accents on their students' listening comprehension. It also examined students' attitudes toward teachers with American-accented English (a native speaker model) and Korean-accented English (a nonnative speaker model). A matched-guised technique was used. A Korean American individual recorded texts in both American-accented English and Korean-accented English. The study randomly assigned 312 Grade 6 Korean students to listen to one of these two recorded oral texts and their comprehension was examined. Next, all of the students listened to both accented-English tapes and their attitudes toward the two speakers (which were in fact the same speaker) were examined. Although the popular belief appears to assume that nonnative accented English would produce a negative effect on students' oral skills, the results failed to find any differences in student performance in terms of comprehension. However, the Korean children thought that the American-accented English guise had better pronunciation, was relatively more confident in her use of English, would focus more on fluency than on accuracy, and would use less Korean in the English class. The students also expressed a preference to have the American-accented English guise as their English teacher.

Recently, the goals of English education in East Asia have gone through a number of major reforms as nations in the region continue to adjust to globalization and the spread of information technology. Many East Asian countries, including China, Taiwan, Korea, and Japan, which have been classified as members in the expanding circle (Kachru, 1992), have started introducing English language instruction at the elementary school level in various forms. The traditional 
Publisher: misc; Journal: tesol:TESOL Quarterly

Job\#: 154732; Volume: 41; Issue: 4; Art\#: 41-4-04; Prod\#: 41-4-04;

Month: December; Year: 2007; Section Head: .

approach of teaching English as a foreign language (EFL) in East Asia has been criticized for putting too much emphasis on grammar, reading, and writing (e.g., Butler \& Iino, 2005; Choi, 2007; Silver, Hu, \& Iino, 2002). East Asian governments have thus set the acquisition of good oral communication skills as one of the primary goals of their elementary English language education. It is not surprising that local teachers' oral communication skills in English (including pronunciation) have become a major concern (Butler, 2004; Lee, 2002; Nunan, 2003).

How important is it that nonnative-English-speaking teachers (NNES teachers) speak "good" English when they are trying to teach elementary school children? More precisely, what effect do the oral abilities of NNES teachers have on the performance of such young English learners? And what attitudes do such young learners hold toward their teachers' English? These questions have taken on increasing significance in Asia in recent years as English language education has been expanded to the elementary school level. This study tries to answer these questions in the case of South Korea, where teachers who typically lack good communicative competencies are now charged with introducing English language education (Lee, 2002).

\section{NATIVE AND NONNATIVE ENGLISH SPEAKERS IN ENGLISH}

\section{TEACHING}

In examining elementary school teachers' English proficiencies, it is important to note that the Korean government is planning to increase the number of native-English-speaking (NES) teachers in their English classes (Yang, 2002). Although the number of NES teachers working in public elementary schools in Korea remains limited, an influx of NES teachers has been hired to work at various private language institutes. Though official statistics are not available, it is 
Publisher: misc; Journal: tesol:TESOL Quarterly

Job\#: 154732; Volume: 41; Issue: 4; Art\#: 41-4-04; Prod\#: 41-4-04;

Month: December; Year: 2007; Section Head: .

believed that many elementary school students take English private lessons from NES teachers after school (Sang-Jae Kim, Ministry of Education \& Human Resources Development, personal communication, November 12, 2003). Moreover, a report recently released by the Organization of Economic Cooperation and Development (OECD) indicated that Korean students were least confident among students in OECD countries in their local school teachers' teaching (note, however, that this survey included students at all grade levels and focused on students' attitudes on all subjects, rather than singling out English education at the elementary school level; OECD, 2003).

The qualifications of NNES and NES teachers have been a heated topic of discussion in the TESOL literature (e.g., Arva \& Medgyes, 2000; Braine, 1999; Brutt-Griffler \& Samimy, 2001;

\section{Canagarajah, 1999; Cook, 1999; Davies, 2003; Kamhi-Stein, 2004; Liu, 1999; Llurda, 2005;}

\section{Medgyes, 1992, 1994; Sheorey, 1986; Widdowson, 1994). Phillipson (1992) has called the belief} that NES teachers are the ideal language teachers (i.e., better qualified as language teachers) the native speaker fallacy; indeed, a number of reports (e.g., Braine, 1999) have indicated that this belief appears to have exerted an undue influence on English teaching in different parts of the world. For example, NNES teachers in Hong Kong appear to believe that NESs are superior to NNESs, particularly in oral communicative abilities, and the teachers' authority and confidence may be threatened by such beliefs (Tang, 1997). NNES teachers in Japan face another type of challenge in teaching English: Parents doubt the ability of NNES teachers to teach English and want their children to be taught by NES teachers (Takada, 2000).

Second language acquisition theory, for its part, has widely used the notion of native speakers and nonnative speakers, with native speakers being considered as the ultimate model of 
Publisher: misc; Journal: tesol:TESOL Quarterly

Job\#: 154732; Volume: 41; Issue: 4; Art\#: 41-4-04; Prod\#: 41-4-04;

Month: December; Year: 2007; Section Head: .

language acquisition. However, this dichotomous notion of native versus nonnative speakers has drawn some criticism (e.g., Davies, ,2003; Edge, 1988; Kachru \& Nelson, 1996). Defining nativeness itself appears to be complicated both psycholinguistically and socioculturally. At the individual level, what factors account for the primary elements of nativeness are still not clear; such elements may include the age of first exposure to the language, linguistic competence, identity, or various other attributes (e.g., Cook, 1999; Davies, 2003). At the societal level, drawing a boundary between native and nonnative varieties of English remains highly controversial.

Some researchers have argued that the construct of nativeness itself is "a non-elective socially constructed identity rather than a linguistic category" (Brutt-Griffler \& Samimy, 2001, p. 100). If this interpretation is correct, it is possible that those same qualifications that appear to favor NES teachers may simply represent a construct of one's perceptions or attitudes toward NNES versus NES teachers and might not bear a direct influence on students' language learning. Although a number of studies have investigated NNES teachers' perceptions regarding NES and NNES teachers' qualifications (e.g., Liu, 1999; Medgyes, 1994), much less is known about learners' perceptions of NES versus NNES teachers' qualifications (Braine, 2005). Moreover, we know very little about the relationship between learners' perceptions and attitudes regarding NES and NNES teachers' qualifications and learner performance. This is especially true with respect to young learners who have just started learning English. This lack of data is somewhat surprising given the fact that a growing number of countries have begun introducing English at younger and younger ages and are planning to hire large numbers of NES teachers. 
Publisher: misc; Journal: tesol:TESOL Quarterly

Job\#: 154732; Volume: 41; Issue: 4; Art\#: 41-4-04; Prod\#: 41-4-04;

Month: December; Year: 2007; Section Head: .

Among various types of qualifications needed for language teachers, the current study focuses on NNES teachers' oral proficiencies in general and pronunciation in particular. (NNES teachers are often considered to have a low proficiency in pronunciation or accentuation; see Medgyes, 1994; Tang, 1997.) Certain varieties of English spoken by native speakers in countries in the centre (Phillipson, 1992), such as general American and received pronunciation, are usually considered to be the model in EFL contexts (Tanabe, 2003). If an instructor's speech does not match this native model, students and their parents, as well as teachers themselves, often express concern over the possible effects of the instructor's accent on his or her students' acquisition of the language.

In the following discussion, accent refers to "the pronunciation features of any spoken variety" (Finegan, 1999, p. 585) including pitch, duration, loudness, and other auditory features of a person's speech.

\section{ATTITUDES TOWARD ACCENTS}

A number of studies have found that accents and dialects do indeed influence listeners' perceptions of speakers (e.g., Fishman, 1977; Giles \& Sassoon, 1983; Giles, Williams, Mackie, \& Rosselli, 1995; McKirnan \& Hamayan, 1984; Oller, Baca, \& Vigil, 1978). The matched-guise technique, which was developed by Lambert, Hodgson, Gardner, and Fillenbaum (1960), has often been used to measure attitudes toward languages, dialects, and accents. In this technique, the participants listen to various tape-recorded speeches and are asked to judge a number of social and psychological traits of the speakers (such as their perceived level of intelligence). The participants are not told that the speech samples actually come from the same speaker. The basic assumption of this technique is that listeners construct speakers' social and psychological traits 
Publisher: misc; Journal: tesol:TESOL Quarterly

Job\#: 154732; Volume: 41; Issue: 4; Art\#: 41-4-04; Prod\#: 41-4-04;

Month: December; Year: 2007; Section Head: .

based on linguistic features of speech such as accents and the rate of speech delivery. The construction of such traits is based on the listeners' perceptions or dispositions toward certain groups of people and certain variations of languages, or what one may call their attitudes. Although researchers have not agreed on the definitions and factors that underlie attitudes (Baker, 1992), the matched-guise technique has been widely used as a methodological tool in studies examining listeners' attitudes toward a variety of languages in various contexts.

Studies have shown that attitudes toward speakers and their accents can differ depending on context (Cargile, 1997; Gallois \& Callan, 1985). A growing number of studies on language attitudes have examined students' attitudes toward the nonnative accents of foreign-born teachers and instructors in light of the increasing number of such instructors at American universities (Nyquist, Abbott, Wulff, \& Sprague, 1991). These studies have shown that teachers with foreign accents are perceived by parents and students to be less intelligent compared with teachers without foreign accents (Nelson, 1991; Solomon, 1991). Rubin (1992) used a version of the matched-guise technique and prepared two sets of videotaped lectures; one was delivered by an Asian lecturer and the other was delivered by a Caucasian lecturer. Using a voiceover, the lectures were, in fact, delivered by a speaker of standard English. In other words, the students were presented with two different visual stimuli (two instructors from different racial backgrounds) but only one audio stimulus (recorded by the same person). Rubin found that even though instructors spoke the same English, undergraduates perceived their instructors' accents differently and, most important, this perception influenced the students' comprehension of their lectures. Edwards (1982) also found that students' evaluations of their teachers' teaching performance were influenced by their accents. Even after controlling for the effects of visual 
Publisher: misc; Journal: tesol:TESOL Quarterly

Job\#: 154732; Volume: 41; Issue: 4; Art\#: 41-4-04; Prod\#: 41-4-04;

Month: December; Year: 2007; Section Head: .

perception (i.e., using photographs to introduce the speakers of recorded lectures) and work performance, the effects of the teachers' accents did not disappear.

Although much of the empirical research on language attitudes has been focused on NESs' attitudes toward varieties of English, some researchers have investigated the relationship between teachers' accents and NNES students' evaluation of such accents. Three studies conducted in EFL contexts in particular serve to illustrate the degree to which this concern is common across various geographies. In Chiba, Matsuura, \& Yamamoto (1995), a group of Japanese college students were asked to listen to six speech samples created by speakers with a variety of accents (namely, with Japanese, Hong Kong Cantonese, Sri Lankan, Malaysian, British, and American English accents). The authors found that the students showed more positive responses toward American- and British-accented English, followed by Japaneseaccented English, and other accented varieties of English. They also found a weak positive correlation between the students' instrumental motivation and acceptance of nonnative accents. In Dalton-Puffer, Kaltenboeck, and Smit (1997), a group of Austrian college students were found to have negative attitudes toward Austrian-accented English (which they perceived to be a foreign accent) and showed a distinct preference for so-called native accents. Among native accents, they most favored the accent with which they were the most familiar, namely, British English. Ladegaard (1998) examined the relationship among high school students' attitudes toward different countries and the varieties of English spoken in those countries. High school students in Denmark considered British English as their language learning model, but they also showed positive attitudes toward American English because of their interest in American culture. 
Publisher: misc; Journal: tesol:TESOL Quarterly

Job\#: 154732; Volume: 41; Issue: 4; Art\#: 41-4-04; Prod\#: 41-4-04;

Month: December; Year: 2007; Section Head: .

The attitudes that elementary school children form toward English accents in EFL contexts have rarely been studied. This lack of attention from researchers has occurred despite the fact that teachers' foreign accents appear to be of particular concern among elementary school teachers as well as among students at the elementary school level in EFL contexts and their parents. Forde (1995) examined Hong Kong students' attitudes toward variations of English and found that British and American English were evaluated favorably when compared with Hong Kong English. This was true even when the students were asked a question concerning their teachers' abilities to teach. (Note, however that the situation in Hong Kong, a former British colony, may differ from that in countries in the expanding circle such as Korea.) Okumura (2005) compared students' attitudes toward various types of English (touching on such factors as the perceived coolness, smartness, honesty, and sincerity of the speakers) among elementary school children and college students in Japan. He found that both groups showed more positive attitudes toward American English than toward Indian English. This result suggests that learners' attitudes may indeed develop at an early age.

It is thus important to understand how learners feel about teachers who do not speak with a certain NES accent as well as how this affects the perceived quality of their teaching. Medgyes (1994) proposed a list of "self-reported" classroom behavioral differences between NES teachers and NNES teachers in his survey of English teachers at different grade levels in 11 countries (p. 58). The differences in behavior between NES and NNES teachers were classified into four categories: individual use of English; general attitudes toward teaching; attitudes toward teaching the language; and attitudes toward teaching culture. This list includes the quality of their pronunciation, their degree of confidence in using English, their casualness, the degree to which 
Publisher: misc; Journal: tesol:TESOL Quarterly

Job\#: 154732; Volume: 41; Issue: 4; Art\#: 41-4-04; Prod\#: 41-4-04;

Month: December; Year: 2007; Section Head: .

they show empathy toward students' problems with learning English, and so on. Medgyes' list is based on teachers' perceptions, and it does not show whether elementary school students perceive the qualifications of NES and NNES teachers in a way that is similar to the way in which teachers perceive such attributes.

\section{Effects of Teachers’ Accents on Students’ Oral Skills}

In addition to understanding children's attitudes toward their teachers' accents in English, in light of the fact that the curricula in many countries where English is not the dominant language strongly emphasize the acquisition of oral communicative skills (especially at the elementary school level), it is also important to examine the effects of teachers' accents on children's oral skills. However, very few studies have focused on the effects of teachers' accents on children's oral skills in EFL contexts.

With respect to listening comprehension of accented speech, the majority of previous studies have examined native listeners' success in comprehending accented speech (i.e., the intelligibility of speech), and have almost exclusively focused on adult listeners. The results of the relatively limited number of studies focusing on learners' comprehension appear to be inconclusive; it is not clear whether learners can more easily comprehend certain types of accented speech.

Eisenstein and Berkowitz (1981) found that adult ESL learners could comprehend standard native speakers' English better than nonstandard English, including foreign-accented English. Among foreign-accented varieties of English, a number of studies have indicated that familiar accents of English are easier for learners to comprehend than unfamiliar accents of English (Tauroza \& Luk, 1997; Wilcox, 1978). However, it is still unclear whether listeners more easily 
Publisher: misc; Journal: tesol:TESOL Quarterly

Job\#: 154732; Volume: 41; Issue: 4; Art\#: 41-4-04; Prod\#: 41-4-04;

Month: December; Year: 2007; Section Head: .

comprehend speech delivered by speakers who share their native language. Smith and Bisazza

(1982) found that although their Japanese students comprehended Japanese-accented English better than U.S. speakers' English, their Indian students comprehended U.S. speakers' English better than Indian-accented English. A more recent study conducted by Major, Fitzmaurice, Bunta, and Balasubramanian (2002) yielded mixed results. By examining adult listeners with different native language backgrounds (Chinese, Japanese, Spanish, and standard American English), they found that Spanish speakers did better when listening to Spanish-accented English speech (even better than when listening to standard American English), whereas Chinese listeners did worse when listening to Chinese-accented English speech. A similarly inconsistent result was also reported by Munro, Derwing, and Morton (2006). The reasons for the inconsistent results among different language groups are not yet clear.

\section{Research Questions}

The current study examined the effect of teachers' accents on Korean elementary school students' listening comprehension skills. It also examined these young learners' attitudes toward teachers with standard American English (a preferred NES model in many EFL contexts, referred to herein as American-accented English) and Korean-accented English. The participants in this study were still beginning to learn English, unlike many of the adult learners who have been the primary participants in studies on this topic to date. The specific research questions examined in the current study are as follows:

1. How do teachers' accents in their English affect elementary school students' English listening comprehension performance in a given EFL context? As is often the concern, does the foreign-accented English of such teachers negatively affect student performance? 
Publisher: misc; Journal: tesol:TESOL Quarterly

Job\#: 154732; Volume: 41; Issue: 4; Art\#: 41-4-04; Prod\#: 41-4-04;

Month: December; Year: 2007; Section Head: .

2. Do elementary school students hold different attitudes regarding the perceived quality of a given teacher's English teaching capabilities based on the two accented-English conditions (i.e., American-accented English and Korean-accented English)? If so, do their responses differ based on their (a) listening comprehension level, (b) experience of having direct contact with native speakers of English, or (c) region (namely, do their responses differ between students studying in the capital city versus those studying in a regional city)?

3. Which attitudinal responses regarding the perceived quality of a given teacher have high associations with the students' preference to have one of the two accented-English speakers as their English teacher?

\section{METHODOLOGY}

\section{Participants}

The participants in the current study were 312 Grade 6 students in Korea. The students were enrolled in two public schools: one in Seoul (the capital) and the other in Daegu, an industrial city that has a reputation for being politically and socially conservative. In contrast to Seoul, one sees few foreigners or English signage in the city. The students were recruited from these two schools to address the possibility that students' attitudes might differ between those who live in the capital city and those who live in regional cities. Both schools were located in a middle-class area in their respective cities. Out of the 312 participants, 173 students were enrolled in the school in Seoul and 139 students were enrolled in the school in Daegu. Approximately half of the students were female and the other half were male.

In Korea, English is currently taught as a foreign language to all elementary school students in Grades 3-6 by native Korean teachers, and oral communication is a major focus in the curriculum. Although some teachers have specialized in teaching English, including some who have previously obtained certification to teach English at the secondary school level, the majority 
Publisher: misc; Journal: tesol:TESOL Quarterly

Job\#: 154732; Volume: 41; Issue: 4; Art\#: 41-4-04; Prod\#: 41-4-04;

Month: December; Year: 2007; Section Head: .

of them are regular classroom teachers. In 1997, to prepare Korean teachers to teach English in their classrooms, the government required all elementary school teachers to participate in a minimum of 120 hours of an in-service teachers' training program wherein teachers take a uniform series of courses on English conversation and English language pedagogy. Currently, there is only one textbook for each grade level used in elementary schools across the nation. The vocabulary and grammatical items that should be introduced at each grade level are also specified based on a uniform national curriculum. For example, the students are expected to acquire 450 words by the end of the Grade 6 (Ministry of Education, Korea, 1997).

In sum, the preparations for English language education at public elementary schools in Korea has been uniform across the country and one could assume that the students in the current study had received similar types of English language education (at least as far as their formal schooling is concerned). It is important to note, however, that many students receive some form of additional English instruction outside of school. Thus, background questionnaires were distributed as one part of the instruments used in the current study as described below.

\section{Materials and Procedures}

The students in the current study were asked to complete the following three tasks:

Comprehension Test: The students were asked to listen to tape-recorded oral materials that had been recorded in either American-accented English or Korean-accented English and then answer a series of comprehension questions related to the oral materials.

Attitudinal Questionnaire: The students were asked to listen a second time to the same oral materials used in the comprehension test, but this time in both American-accented English and Korean-accented English. The 
Publisher: misc; Journal: tesol:TESOL Quarterly

Job\#: 154732; Volume: 41; Issue: 4; Art\#: 41-4-04; Prod\#: 41-4-04;

Month: December; Year: 2007; Section Head: .

\footnotetext{
students were then asked to respond to attitudinal questions regarding various qualities of the "two speakers" or guises (e.g., how "good" their pronunciation was).

Background Questionnaire: The students were asked questions regarding their experiences (if any) with native English speakers.
}

The procedural instructions were given entirely in Korean at the beginning of each task to ensure that all of the students fully understood what to do.

The listening comprehension test developed for this study consisted of three sections that roughly correspond to the three different grade levels regulated in the 7th Korean National Curriculum for English. The vocabulary, syntactic complexity, and length of sentences used in the oral materials and test items were designed to be appropriate for 5 th graders (and younger) in Section 1 of the listening comprehension test, for 6th graders in Section 2 of the test, and for 7 th graders (and up) in Section 3 of the test. As such, Section 1 was intended to be easy for our participants (6th graders), Section 2 was intended to be at their grade level, and Section 3 was intended to be difficult for them. Many in Korea are significantly concerned regarding the wide gaps in English proficiency levels among elementary school students, particularly at the upper grade levels. The decision to incorporate three sections in the test was thus made to account for the assumed diversity of proficiency levels among the participants.

Section 1 asked students to answer a series of short questions about pictures and oral materials. The questions themselves included 1-3 short sentences. Both Sections 2 and 3 were composed of an oral text followed by comprehension questions about the text. To prevent the comprehension test from becoming a de-facto memory test for Sections 2 and 3, the texts were first read in their entirety and then the texts were read paragraph by paragraph, with one or two 
Publisher: misc; Journal: tesol:TESOL Quarterly

Job\#: 154732; Volume: 41; Issue: 4; Art\#: 41-4-04; Prod\#: 41-4-04;

Month: December; Year: 2007; Section Head: .

comprehension questions between paragraphs. The comprehension questions were designed simply to check whether the students could capture the main information from the oral materials and did not include any questions involving higher order thinking skills. The comprehension questions for all three sections were in the format of a multiple-choice test, which was presented entirely in English. The comprehension test contained 20 items.

The current study used a matched-guised technique (Lambert, et al., 1960). A KoreanAmerican female with teaching experience recorded all three sections of the listening comprehension test. Studies using the matched-guise technique often use recordings of different languages and dialects by the same speaker (or speakers) because factors other than the targeted linguistics features, such as voice quality (e.g., softness of voice, pitch, etc.) might affect listeners' attitudes toward such speakers. In the present case, one may consider the recorder a bidialectal speaker; although she spoke North American accented English in most daily contexts, she could also speak Korean-accented English in certain contexts. A bidialectal speaker has similarly been used in previous studies employing the matched-guised technique such as in Doss and Gross (1992) and Seggia, Fulmizi, and Stewart (1982).

The bidialectal speaker used in this study recorded the oral materials and test questions in both American-accented English and Korean-accented English. According to Kwon (1999), the primary characteristics of English spoken by Korean speakers include (a) replacement of certain phonemes (e.g., replacements of /f/ with /p/, /v/ with /b/, / / / with /d/, and /z/ with /j/); (b) influence from Korean assimilation (e.g., consonants before a nasal phoneme become nasalized as in "stop now" to "stom now"); and (c) changes in stress patterns due to English loan words used in Korean (e.g., stressing the [e] in "Neì York" as opposed to stressing the [o] as in "New 
Publisher: misc; Journal: tesol:TESOL Quarterly

Job\#: 154732; Volume: 41; Issue: 4; Art\#: 41-4-04; Prod\#: 41-4-04;

Month: December; Year: 2007; Section Head: .

Yoìrk") (p. 30-32). Therefore, two researchers trained in linguistics went over the recordings to ensure that the recorded Korean-accented English had notable and consistent deviations in certain phonemes and stress patterns. Moreover, four native speakers of North-American English (all of whom were trained in linguistics) were then asked to judge holistically the degree to which the recorded stories were accented in both sets of recordings. These judges scored the degree of foreign accentuation using a 5-point scale (where 1 indicates no perceivable foreign accent and 5 indicates a heavy foreign accent). The mean scores for the Korean-accented version and the American-accented version were 3.5 and 1, respectively. ${ }^{1}$ As such, the degree of accentuation was clearly different enough to be perceived by the judges. The speed of speech delivery and voice quality were controlled for in producing the recordings.

About half of the students in each school were randomly assigned to take the comprehension test based on the American-accented English recording $\left(N_{\mathrm{AE}}=159\right)$, and the other half were assigned to take the test based on the Korean-accented English recording $\left(N_{\mathrm{KE}}=153\right)$. After the listening comprehension test, all of the students listened to the same oral materials used in the comprehension test one more time. The second time, however, the students listened to both the American-accented English recording and the Korean-accented English recording. The students were asked to listen to both accented English materials because it was assumed to be easier for young learners to make judgments about various attitudinal questions if they had a chance to compare the two types of accented English. The order of the two accented-English recordings was counterbalanced. After listening to both versions, the students were then asked to judge various traits (qualities) of the two teachers (i.e., guises) on the tape. 
Publisher: misc; Journal: tesol:TESOL Quarterly

Job\#: 154732; Volume: 41; Issue: 4; Art\#: 41-4-04; Prod\#: 41-4-04;

Month: December; Year: 2007; Section Head: .

The current study focused on seven specific measures to assess the students' perceptions of the two teachers (two guises) they heard in the recordings. These aspects were chosen based on the self-reported behavioral differences between NES teachers and NNES teachers cited in Medgyes (1994) as described earlier. Seven items were chosen from among the various behaviors listed in Medgyes because it was hypothesized that they could serve as indicators of some of the leading in-class behavioral differences between NES teachers and NNES teachers. The items were adopted to suit the specific context of the Korean elementary school students in the current study. These traits were also assumed to be relatively easy to judge for elementary school students, based on the results of a pilot study that focused on a small number of Korean elementary school students.

Out of the seven items, two items were related to the teacher's ability to use English (ability to use English, corresponding to attitudes towards individual use of English in Medgyes, 1994), three items were related to the teacher's pedagogical strategies to teach English (English teaching strategies, corresponding to attitudes towards teaching the language in Medgyes), and two items were related to strategies for teaching in general (general teaching strategies, corresponding to the teachers' general attitudes towards teaching in Medgyes).

\section{Ability to Use English}

1. The perceived "goodness" of their pronunciation.

2. The teachers' (guises') degree of confidence in their use of English.

\section{English Teaching Strategies}

3. The degree of focus on accuracy versus fluency in their teaching. 
Publisher: misc; Journal: tesol:TESOL Quarterly

Job\#: 154732; Volume: 41; Issue: 4; Art\#: 41-4-04; Prod\#: 41-4-04;

Month: December; Year: 2007; Section Head: .

4. The degree to which they were expected to use Korean in their classrooms.

5. Their ability to explain the similarities and differences between the English and Korean languages.

\section{General Teaching Strategies}

6. The strictness/casualness of the teachers.

7. their degree of empathy toward the problems that Korean students have in learning English.

In addition to these seven items, the students were asked to judge the extent to which they wished to have these "teachers" (guises) as their English teachers (teacher preference). Thus, the students were asked to judge eight attitudinal questions in total using a 7-point scale for each question. Based on previous studies such as Medgyes (1994), the scales were created in such a way that higher numbers reflect stronger expected traits of NS teachers. For example, Medgyes found that NNES teachers perceived NES teachers as more casual and less strict than NNES teachers are in their teaching style. To reflect such traits, 1 indicates strictness and 7 indicates casualness in the present scale. This attitudinal judgment was conducted in Korean.

For their final task, the students were asked to fill out a brief questionnaire. This questionnaire covered two basic areas: (a) whether the students had any experience of traveling to or staying in an English-speaking country; and (b) whether the students had ever learned English directly from a native-English-speaking teacher inside or outside of their school. This questionnaire was given in Korean.

All three tasks took the students approximately 40 minutes, including time spent instructing the students on how to complete the procedures. 
Publisher: misc; Journal: tesol:TESOL Quarterly

Job\#: 154732; Volume: 41; Issue: 4; Art\#: 41-4-04; Prod\#: 41-4-04;

Month: December; Year: 2007; Section Head: .

\section{RESULTS}

\section{Listening Comprehension}

I first examined whether the accents in English affected the young learners' performance on the listening comprehension test. The analysis failed to find any significant differences in the students' performance between the two accented English conditions. Before examining mean performance, I calculated the coefficient-alpha reliability of the 20 items in the comprehension test so as to ensure that the test items were reasonably reliable. The coefficient-alpha reliability was 0.70 and thus the test items were judged to have a reasonably high degree of reliability. The means and the standard deviations for American-accented English and Korean-accented English were as follows: American-accented English $(M=10.75, S D=3.46)$ and Korean-accented English $(M=11.05, S D=3.40)$. After employing a series of diagnostic examinations to ensure that the independency, normality, and homogeneity of variance assumptions were met, a oneway ANOVA was used to compare the mean scores of the two accented conditions. The result indicated that the ANOVA failed to find differences in mean scores between the two accented English conditions $(F(1,311)=0.56, p=0.45)$.

\section{Students’ Attitudes Toward American-Accented English and Korean-Accented English}

An examination of the students' attitudes toward the two accented-English guises revealed that there were indeed some significant differences in attitudes. Table 1 summarizes the results of this analysis. As mentioned in the methodology section, all of the students listened to both the Korean-accented and American-accented English in this part of the study. Thus, repeated measures of analysis of variance (with two within-subject factors: accents and attitudes) were 
Publisher: misc; Journal: tesol:TESOL Quarterly

Job\#: 154732; Volume: 41; Issue: 4; Art\#: 41-4-04; Prod\#: 41-4-04;

Month: December; Year: 2007; Section Head: .

used to examine whether participants showed a difference in attitudes toward the two types of English overall. ${ }^{2}$ The results indicated that there was a within-subject interaction effect $(F(4.46$, $\left.1216.8)=3.48, p<0.01, \eta^{2}=0.01\right)$. The results further indicated that there were within-subject main effects for both accents $\left(F(1,273)=46.31, p<0.0001, \eta^{2}=0.15\right)$ and attitudes $(F(3.86$, $\left.1054.5)=25.74, p<0.0001, \eta^{2}=0.10\right){ }^{3}$ The students' attitudes significantly differed between the two accented English conditions. Finally, a series of ANOVAs with repeated measures were used to examine the differences in attitudes toward both the American-accented English speaker and the Korean-accented English speaker for each of the eight attitudinal variables. Significant differences were found with regard to the following attitudinal variables: both of the test items addressing perceived ability to use English (i.e., quality of the teacher's pronunciation and their perceived confidence in the use of English), two of the three items addressing English teaching strategies (i.e., their perceived focus on fluency versus accuracy and use of Korean in classrooms), and finally, the degree to which the students wished to have the guises as their English teachers. ${ }^{4}$ Neither of the items regarding General teaching strategies was found to generate significant differences in student attitudes toward the two guises. The Korean elementary school children thought that the American-accented English speaker (compared with the Korean-accented English speaker) had better pronunciation, was more confident in her use of English, would focus more on fluency, and would use less Korean in the English class. The students also expressed a stronger preference to have the American-accented English speaker as their English teacher than the Korean-accented English speaker.

Because differences were found in the students' attitudes, a series of analyses were conducted to answer the follow-on set of questions pertaining to the second research question 
Publisher: misc; Journal: tesol:TESOL Quarterly

Job\#: 154732; Volume: 41; Issue: 4; Art\#: 41-4-04; Prod\#: 41-4-04;

Month: December; Year: 2007; Section Head: .

addressed in this study. Namely, the analyses were focused on whether the students' responses to attitudinal items differed based on their (a) listening comprehension level, (b) experience of having direct contact with native speakers of English, and (c) geographical region. The results revealed that the students' attitudes in response to certain items (specifically, the two items regarding perceived ability to use English) differed only between high and low comprehension groups; no differences in attitude were found based on the other two variables (i.e., experience of direct contact and regions).

The students' standardized scores ( $z$ scores) on the comprehension test were used to divide the students into two groups: a low comprehension group $\left(N_{\mathrm{L}}=155\right)$ and a high comprehension group $\left(N_{\mathrm{H}}=157\right)$. To examine the effect of the students' experience with direct contact with native English speakers, based on the students' responses to the second question in the questionnaire the students were again classified into two groups: those who had experienced learning English directly from native speakers of English $\left(N_{1}=171\right)$ and those who had not $\left(N_{0}=\right.$ 116). Although this is clearly a gross classification (given that the questionnaires did not address either the quality or quantity of English instruction from native English speakers), the effect of this variable could be worth examining given the fact that a growing number of parents are sending their children to private English institutes to provide them with instruction from native speakers.

The descriptive statistics for the students' responses related to the three variables tested (i.e., comprehension level, direct contact, and region) are summarized in Tables 2-4. In examining the effect of these three variables on the students' attitudinal responses, a MANOVA was used. Among the eight attitudinal items originally prepared, only those attitudinal items that were 
Publisher: misc; Journal: tesol:TESOL Quarterly

Job\#: 154732; Volume: 41; Issue: 4; Art\#: 41-4-04; Prod\#: 41-4-04;

Month: December; Year: 2007; Section Head: .

found to be significant (five items in total) were used as dependent variables for the subsequent analysis. Three between-subject variables were found: comprehension level, direct contact, and region. The accent was used as a repeated measure. The results revealed a between-subject interaction effect between direct contact and region $\left(F(1,254)=8.18, p<0.01, \eta^{2}=0.03\right)$ and a between-subject main effect for comprehension level $\left(F(1,254)=9.10, p<0.005, \eta^{2}=0.04\right)$. I ran additional posthoc analyses and found that only one item, confidence, was significantly related to comprehension level $\left(F(1,295)=7.86, p<0.005, \eta^{2}=0.03\right)$. The students' scores for the guises' confidence were different depending on their listening comprehension performance. The students with higher comprehension performance gave higher confidence scores for both accented-English guises than the students with lower comprehension performance.

\section{Attitudinal Responses Related to the Students' Wish to Have Either Guise as Their}

\section{Teacher}

Pearson correlation coefficients were used to examine which attitudinal responses were related to the students' wish to have either guise as their English teacher (teacher preference). As Table 5 shows, the two attitudinal items regarding the ability to use English (i.e., pronunciation and confidence) had relatively high positive correlations with teacher preference for both accented guises. Among the three items for English teaching strategies, fluency was moderately related to teacher preference only for the American-accented English guise. It is interesting that the ability to explain the difference between English and Korean was relatively highly correlated with teacher preference (note that the scale was reversed for this item, with lower numbers indicating a superior ability to explain the differences between the two languages). This result indicates that the students prefer teachers who are better able to explain the differences between 
Publisher: misc; Journal: tesol:TESOL Quarterly

Job\#: 154732; Volume: 41; Issue: 4; Art\#: 41-4-04; Prod\#: 41-4-04;

Month: December; Year: 2007; Section Head: .

English and Korean. Regarding the two items for general teaching strategies, empathy was highly correlated with teacher preference for both accented conditions (note that this item also had a reverse scale), and perceived strictness had relatively lower correlations with teacher preferences for both accented guises.

\section{DISCUSSION}

The current study investigated the effect of elementary school teachers' accents on students' listening comprehension in English as well as students' attitudes toward American-accented English (a preferred native model) and Korean-accented English (a nonnative model). The study also investigated how the students' attitudinal responses toward selected qualities of teachers related to the students' desire to have them as their English teachers. Many commentators and policymakers in East Asia have expressed concern that local teachers' accents might have a negative effect on students' oral English performance. However, as far as listening comprehension is concerned, the analysis of the test used in this study failed to find any significant differences in students' performance between the American-accented English and Korean-accented English conditions. The study did find significant differences in the students' attitudes toward the teachers (guises) with American-accented English and Korean-accented English regarding their goodness of pronunciation, confidence in their use of English, focus on fluency versus accuracy, and use of Korean in the classroom. The students' responses regarding the two teachers' (guises') confidence were also significantly different between the low and high performers on the comprehension test. Regional differences and direct experience with native speakers did not make any significant attitudinal difference. The study also found that regardless of the teachers' (guises') accents, the students' desire to have them as their teachers was highly 
Publisher: misc; Journal: tesol:TESOL Quarterly

Job\#: 154732; Volume: 41; Issue: 4; Art\#: 41-4-04; Prod\#: 41-4-04;

Month: December; Year: 2007; Section Head: .

related to the students' responses regarding the following teacher qualities: pronunciation, confidence, empathy, and ability to explain the differences between English and Korean.

Previous studies have indicated some of the factors that influence listeners' abilities to comprehend foreign-accented speech (i.e., intelligibility of speech). Bearing in mind that most of these findings have been based on native listeners' success in comprehending accented speech, such factors include grammar and pronunciation (Varonis \& Gass, 1982) as well as each listener's familiarity with a particular accent, a particular speaker, the topic of the speech, and familiarity with nonnative speakers' speech in general (Gass \& Varonis, 1984). Specific elements of speech, such as prosodic features of pronunciation, have been identified as also having some influence (e.g., Anderson-Hsieh, Johnson, \& Koehler, 1992). It is important to note, however, that it is still unclear which features have the most influence on intelligibility (Munro \& Derwing. 1995). There is some evidence that native and nonnative listeners show similar responses to certain prosodic features of accented speech (see, e.g., Field, 2005, for the case of lexical stress). However, we still have only limited knowledge regarding whether or not such factors are equally detrimental to nonnative speakers' ability to comprehend various types of accented speech.

Efforts were made to include the major features of Korean speakers' English in the Koreanaccented English used in this study. However, more systematic research is necessary to understand which elements of NNES teachers' speech may affect student comprehension skills and the underlying mechanism of how this occurs. Moreover, the NNES teachers in Korea presumably have varying degrees of foreign accents in their English, and thus the degree to which their English was accented can be expected to differ from the level of accent used in the current study. It is possible that the Korean-accented stimuli used in this study, although 
Publisher: misc; Journal: tesol:TESOL Quarterly

Job\#: 154732; Volume: 41; Issue: 4; Art\#: 41-4-04; Prod\#: 41-4-04;

Month: December; Year: 2007; Section Head: .

recognized as having a distinct foreign accent by experts in linguistics, simply may not reach a threshold level at which it begins to affect student comprehension. Although one can assume that such a threshold may be influenced by a number of factors, including the nature of the tasks being performed, the student-teacher relationship, and other contextual factors, identifying the level of accentuation at which teachers become intelligible by their students would be useful for both teacher training and teacher certification exams.

Even though the analysis failed to find differences in student comprehension under the American-accented and Korean-accented English conditions, the students' attitudinal responses toward the two accented English guises used in this study were found to be small but significantly different. It is interesting to note that although differences were found on the two items regarding teachers' ability to use English (i.e., pronunciation and confidence) and selected items regarding teachers' English teaching strategies (i.e., focus on fluency and use of Korean in class), no significant differences were found on items regarding the teachers' general teaching strategies. The study's last analysis also suggests that students may perceive that certain qualifications are more important to NES teachers while a different set (or subset) of qualities are more important for NNES teachers. Various other qualifications may be perceived to be important regardless of NES versus NNES status.

These findings are still suggestive, however, given the inherent unreliability of the small number of items and small effect sizes obtained from the statistical analyses. It is important to increase the number of items and develop instruments with better reliability for future research on the questions addressed in this study. The participants' background information also needs to be further evaluated. For instance, it is widely acknowledged that socioeconomic status is 
Publisher: misc; Journal: tesol:TESOL Quarterly

Job\#: 154732; Volume: 41; Issue: 4; Art\#: 41-4-04; Prod\#: 41-4-04;

Month: December; Year: 2007; Section Head: .

associated with both attitudes and academic performance. Previous studies investigating adult learners' perceptions of NES versus NNES teacher qualifications also suggested that learners' individual tastes, experiences, and personal backgrounds (including gender) influence their perceptions of teachers in complicated ways (Benke \& Medgyes, 2005; Mahboob, 2004; Pacek, 2005). The current study recruited middle-class students only, and it does not explore the effects of other variables such as gender, learning style, personality factors, teacher qualifications, prior achievement, and other contextual factors that are likely to affect attitudes toward native and nonnative speakers. Performing these types of analyses would require more extensive background measures and multilevel modeling techniques that would allow researchers to simultaneously examine individual-level influences (e.g., individual-child-level socioeconomic status), teacher-level influences (e.g., the effect of current teacher qualifications), and schoollevel influences (e.g., school resources) on attitudes and comprehension level. It would also require researchers to obtain larger sample sizes and measure significantly more items. To the extent possible, future studies should incorporate more comprehensive measures that would allow for multilevel modeling analyses. These measures may then allow researchers to create more nuanced profiles of which students are more likely to show a preference for certain accented-English-speaking teachers.

The current study is one of the first to investigate the effect of teachers' accented English on students' oral performance at the elementary school level as well as of students' attitudes toward accented-English speakers from a pedagogical point of view. Given the fact that currently the majority of English learners in the world are taught by NNES teachers (Brutt-Griffler, 2002) and that English is being introduced at younger and younger grade levels as a foreign language in 
Publisher: misc; Journal: tesol:TESOL Quarterly

Job\#: 154732; Volume: 41; Issue: 4; Art\#: 41-4-04; Prod\#: 41-4-04;

Month: December; Year: 2007; Section Head: .

many parts of the world, more research is called for on this topic. Such research would be particularly useful for teaching younger populations of students and would be of substantial practical and theoretical value. In this regard, I believe that the current study represents a promising start toward understanding the ways in which English teaching can be improved.

\section{ACKNOWLEDGMENTS}

A preliminary analysis of part of the data discussed herein was reported in Working Papers in Educational Linguistics at the University of Pennsylvania. I am grateful for the assistance of both Sung Hwi Choo and Vi-Nhuan Le, who assisted me with the collection and analysis of the data in this study.

\section{THE AUTHOR}

Yuko Goto Butler is an assistant professor in the Language and Literacy in Education Division of the Graduate School of Education at the University of Pennsylvania, Philadelphia, United States. Her research interests include assessment and the role of awareness in learning and teaching, especially in English and foreign language education at the elementary school level.

\section{REFERENCES}

$<$ jrn>Anderson-Hsieh, J., Johnson, R., \& Koehler, K. (1992). Native speaker reactions to learners'spoken interlanguage. Language Learning, 30, 365-396.</jrn>

$<$ jrn $>$ Arva, V., \& Medgyes, P. (2000). Native and non-native teachers in the classroom. System, 28, 355-372.</jrn>

$<$ eref>Baguley, T. (2003). An introduction to sphericity. Retrieved November 7, 2007, from http://homepages.gold.ac.uk/aphome/spheric.html</eref $>$ 
Publisher: misc; Journal: tesol:TESOL Quarterly

Job\#: 154732; Volume: 41; Issue: 4; Art\#: 41-4-04; Prod\#: 41-4-04;

Month: December; Year: 2007; Section Head: .

$<$ bok>Baker, C. (1992). Attitudes and language. Clevedon, England: Multilingual Matters. $<$ /bok $>$

$<$ edb $>$ Benke, E., \& Medgyes, P. (2005). Differences in teaching behavior between native and non-native speaker teachers: As seen by the learners. In E. Llurda (Ed.), Nonnative language teachers: Perceptions, challenges, and contributions to the profession (pp. 195-215). New York: Springer $</$ edb $>$

$<\mathrm{edb}>$ Braine, G. (1999). (Ed.). Non-native educators in English language teaching. Mahwah, NJ: Lawrence Erlbaum. $</$ edb $>$

$<$ edb $>$ Braine, G. (2005). A history of research on non-native speaker English teachers. In E. Llurda (Ed.), Non-native language teachers: Perceptions, challenges, and contributions to the profession (pp. 13-23). New York: Springer $</$ edb $>$

$<$ bok>Brutt-Griffler, J. (2002). World English: A study of its development. Clevedon, England: Multilingual Matters. $</$ bok $>$

$<$ jrn>Brutt-Griffler, J., \& Samimy, K. K. (2001). Transcending the nativeness paradigm. World Englishes, 20, 99-106.</jrn>

$<$ jrn>Butler, Y. G. (2004). What level of English proficiency do elementary school teachers need to attain in order to teach EFL? Case studies from Korea, Taiwan, and Japan. TESOL Quarterly, 38, 245-278.</jrn>

$<$ jrn>Butler, Y. G., \& Iino, M. (2005). Current Japanese reforms in English language education: The 2003 “Action Plan.” Language Policy, 4, 25-45.</jrn> 
Publisher: misc; Journal: tesol:TESOL Quarterly

Job\#: 154732; Volume: 41; Issue: 4; Art\#: 41-4-04; Prod\#: 41-4-04;

Month: December; Year: 2007; Section Head: .

<edb>Canagarajah, A. S. (1999). Interrogating the "native speaker fallacy": Nonlinguistic roots, non-pedagogical results. In G. Braine (Ed.), Non-native educators in English language teaching (pp. 77-92). Mahwah, NJ: Lawrence Erlbaum. $</$ edb $>$

$<$ jrn>Cargile, A. C. (1997). Attitudes towards Chinese-accented speech. Journal of Language and Social Psychology, 16, 434-443.</jrn>

$<$ jrn $>$ Chiba, R., Matsuura, H., \& Yamamoto, A. (1995). Japanese attitudes towards English accents. World Englishes, 14, 77-86.</jrn>

Choi, Y. H. (2007). The history and policy of English language education in Korea. In Y. H. Choi \& B. Spolsky (Eds.), English education in Asia: History and policies (pp. 33-66). Seoul, Korea: Asia TEFL.**Instruction to Composition: Please code as an edited book.**

$<$ bok $>$ Cohen, J. (1988). Statistical power analysis for the behavior sciences. Hillsdale, NJ: Lawrence Erlbaum. $</$ bok $>$

$<\mathrm{jrn}>$ Cook, V. (1999). Going beyond the native speaker in language teaching. TESOL Quarterly, 33, 185-210.</jrn>

$<$ jrn>Dalton-Puffer, C., Kaltenboeck, G., \& Smit, U. (1997). Learner attitudes and L2 pronunciation in Austria. World Englishes, 16, 115-128.</jrn>

$<$ bok>Davies, A. (2003). The native speaker: Myth and reality. Clevedon, England: Multilingual Matters. $</$ bok $>$

$<$ jrn $>$ Doss, R. C., \& Gross, A. M. (1992). The effects of Black English on stereotyping in intraracial perceptions. The Journal of Black Psychology, 18(2), 47-58.</jrn> $<$ jrn>Edge, J. (1988). Native, speakers and models. JALT Journal, 9, 153-157.</jrn> 
Publisher: misc; Journal: tesol:TESOL Quarterly

Job\#: 154732; Volume: 41; Issue: 4; Art\#: 41-4-04; Prod\#: 41-4-04;

Month: December; Year: 2007; Section Head: .

$<$ edb $>$ Edwards, J. R. (1982). Language attitudes and their implications among

English speakers. In E. B. Ryan \& H. Giles (Eds.), Attitudes toward language variation (pp. 20-33). London: Edward Arnold. $</$ edb $>$

$<$ jrn>Eisenstein, M. R., \& Berkowitz, D. (1981). The effect of phonological variation on adult learner comprehension. Studies in Second Language Acquisition, 4, 75-80.</jrn>

Field, J. (2005). Intelligibility and the listener: the role of lexical stress. TESOL Quarterly,

39, 399-423.

$<$ bok>Finegan, E. (1999). Language: Its structure and use. Orlando, FL: Harcourt Brace. $</$ bok $>$

$<$ edb $>$ Fishman, J. A. (1977). Language and ethnicity. In H. Giles (Ed.), Language, ethnicity, and intergroup relations (pp. 15-57). London: Academic Press. $</$ edb $>$

$<\mathrm{jrn}>$ Forde, K. (1995). A study of learner attitudes towards accents of English. HongKong Polytechnic University Working Papers in ELT \& Applied Linguistics, 1, 59-76.</jrn>

$<$ edb $>$ Gallois, C., \& Callan, V. J. (1985). Situational influences on perceptions of accented speech. In J. Forgas (Ed.), Language and social situations (pp. 159-173). New York: Spinger-Verlag. $</$ edb $>$

$<$ jrn $>$ Gass, S., \& Varonis, F. M. (1984). The effect of familiarity on the comprehensibility of nonnative speech. Language Learning, 34, 65-89.</jrn>

$<$ jrn $>$ Giles, H., \& Sassoon, C. (1983). The effects of speakers' accent, social class background and message style on British listener's social judgments. Language \& Communication, 3, 305-313.</jrn> 
Publisher: misc; Journal: tesol:TESOL Quarterly

Job\#: 154732; Volume: 41; Issue: 4; Art\#: 41-4-04; Prod\#: 41-4-04;

Month: December; Year: 2007; Section Head: .

$<$ jrn>Giles, H., Williams, A., Mackie, D. M., \& Rosselli, F. (1995). Reactions to Anglo- and Hispanic-American accented speakers: Affect, identity, persuasion, and the English-only controversy. Language \& Communication, 15, 107-120.</jrn>

$<$ edb $>$ Kachru, B. B. (1992). Teaching World Englishes. In B. B. Kachru (Ed.), The other tongue: English across cultures (pp. 355-365). Urbana: University of Illinois Press. $</$ edb $>$

$<$ edb $>$ Kachru, B. B., \& Nelson, C. L. (1996). World Englishes. In S. L. McKay \& N. H. Hornberger (Eds.), Sociolinguistics and language teaching (pp. 71-102). New York: Cambridge University Press. $</$ edb $>$

$<\mathrm{edb}>$ Kamhi-Stein, L. (Ed.). (2004). Learning and teaching from experience: Perspectives on nonnative English-speaking professionals. Ann Arbor, MI: University of Michigan Press. $</$ edb $>$

$<$ edb $>$ Kwon, O. (1999). Kankoku-no eigokyoiku-to kankokushiki-eigo [English education in Korea and Korean English]. In N. Honma (Ed.), Ajia-no eigo [Varieties of English in Asia] (pp. 23-41). Tokyo: Kuroshio Publishing.</edb $>$

$<$ jrn>Ladegaard, H. J. (1998). National stereotypes and language attitudes: The perception of British, American, and Australian language and culture in Denmark. Language \& Communication, $18,251-274 .</ \mathrm{jrn}>$

<jrn>Lambert, W. E., Hodgson, R. C., Gardner, R. C., \& Fillenbaum, S. (1960). Evaluative reactions to spoken languages. Journal of Abnormal and Social Psychology, 60, 44-51.</jrn> 
Publisher: misc; Journal: tesol:TESOL Quarterly

Job\#: 154732; Volume: 41; Issue: 4; Art\#: 41-4-04; Prod\#: 41-4-04;

Month: December; Year: 2007; Section Head: .

$<\mathrm{jrn}>$ Lee, K. (2002). Investigation into teacher proficiency for communicative English teaching in elementary schools. Primary English Education, 8, 235-264.</jrn>

$<$ jrn>Liu, J. (1999). Nonnative-English-speaking professionals in TESOL. TESOL

Quarterly, 33, 85-102.</jrn>

$<\mathrm{edb}>$ Llurda, E. (Ed.). (2005). Non-native language teachers: Perceptions, challenges, and contributions to the profession. New York: Springer. $</ \mathrm{edb}>$

$<$ edb $>$ Mahboob, A. (2004). Native or nonnative: What do students enrolled in an intensive English program think? In L. D. Kamhi-Stein (Ed.), Learning and teaching from experience: Perspectives on nonnative English-speaking professionals (pp. 121-147). Ann Arbor, MI: The University of Michigan Press. $</$ edb $>$

$<$ jrn $>$ Major, R. C., Fitzmaurice, S. F., Bunta, F., \& Balasubramanian, C. (2002). The effects of nonnative accents on listening comprehension: Implications for ESL assessment. TESOL Quarterly, 36, 173-190.</jrn>

$<$ jrn>McKirnan, D. J., \& Hamayan, E. V. (1984). Speech norms and attitudes toward outgroup members: A test of a model in bicultural context. Journal of Language and Social Psychology, 3, 21-38.</jrn>

$<$ jrn>Medgyes, P. (1992). Native or non-native: Who's worth more? ELT Journal, 46, $340-349 .</ j \mathrm{rn}>$

$<$ bok>Medgyes, P. (1994). The non-native teacher. London: Macmillan. $<$ bok $>$ 
Publisher: misc; Journal: tesol:TESOL Quarterly

Job\#: 154732; Volume: 41; Issue: 4; Art\#: 41-4-04; Prod\#: 41-4-04;

Month: December; Year: 2007; Section Head: .

$<$ bok>Ministry of Education, Korea. (1997). Chojungdeung hakgyo gyoyuk gwajeung: Gukmin gongtong gibon gyoyuk gwajeung [The elementary and middle school curriculum-National common basic curriculum]. Seoul, Korea: Author. $<$ bok $>$

$<$ jrn>Munro, M. J., \& Derwing, T. M. (1995). Foreign accent, comprehensibility, and intelligibility in the speech of second language learners. Language Learning, 45, 7397. $</ \mathrm{jrn}>$

Munro, M. J., Derwing, T. M., \& Morton, S. L. (2006). The mutual intelligibility of L2 speech. Studies in Second Language Acquisition, 26, 111-131.

$<$ edb $>$ Nelson, G. L. (1991). Effective teaching behavior for international teaching assistants. In J. D. Nyquist, R. D. Abbott, D. H. Wulff, \& J. Sprague (Eds.), Preparing the professorate of tomorrow to teach (pp. 427-434). Dubuque, IA: Kendall Hunt. $</$ edb $>$

$<$ jrn $>$ Nunan, D. (2003). The impact of English as a global language on educational policies and practices in the Asia-Pacific region. TESOL Quarterly, 37, 589-613.</jrn>

<edb>Nyquist, J. D., Abbott, R. D., Wulff, D. H., \& Sprague, J. (Eds.). (1991).

Preparing the professorate of tomorrow to teach. Dubuque, IA: Kendall Hunt. $</$ edb $>$

$<$ jrn $>$ Okumura, S. (2005). Eigo akusento-ni taisuru nihonjin jido-no taido [Japanese elementary school students' attitudes toward varieties of English accents]. JAFLE Bulletin, 1, 57-74. $</ \mathrm{jrn}>$

$<$ jrn>Oller, J. W., Baca, L., \& Vigil, F. (1978). Attitudes and attained proficiency in ESL: A sociolinguistic study of Mexican Americans in the Southwest. TESOL Quarterly, 11, $173-183 .</$ jrn $>$ 
Publisher: misc; Journal: tesol:TESOL Quarterly

Job\#: 154732; Volume: 41; Issue: 4; Art\#: 41-4-04; Prod\#: 41-4-04;

Month: December; Year: 2007; Section Head: .

$<$ eref $>$ Organization of Economic Cooperation and Development. (2003). Education statistics and indicators. Retrieved March 15, 2004, from

http://www.oecd.org/department/0,2688,en_2649_34515_1_1_1_1_1,00.html</eref>

$<$ edb>Pacek, D. (2005). "Personality not nationality": Foreign students' perceptions of a non-native speaker lecturer of English at a British university. In E. Llurda (Ed.), Nonnative language teachers: Perceptions, challenges, and contributions to the profession (pp. 243-262). New York: Springer $</$ edb $>$

$<$ bok>Phillipson, R. (1992). Linguistic imperialism. Oxford: Oxford University Press. $</$ bok $>$

$<$ jrn $>$ Rubin, D. L. (1992). Nonlanguage factors affecting undergraduates' judgments of nonnative English-speaking teaching assistants. Research in Higher Education, 33, 511531. $<$ jrn $>$

$<$ jrn>Seggia, I., Fulmizi, C., \& Stewart, J. (1982). Evaluations of personality traits and employment suitability based on various Australian accents. Australian Journal of Psychology, 34, 345-357. </jrn>

$<\mathrm{jrn}>$ Sheorey, R. (1986). Error perceptions of native-speaking and non-nativespeaking teachers of ESL. ELT Journal, 40, 306-312.</jrn>

$<$ bok>Silver, R. E., Hu, G., \& Iino, M. (2002). English language education in China, Japan, and Singapore. Singapore: National Institute of Education, Nanyang Technological University.</bok $>$ 
Publisher: misc; Journal: tesol:TESOL Quarterly

Job\#: 154732; Volume: 41; Issue: 4; Art\#: 41-4-04; Prod\#: 41-4-04;

Month: December; Year: 2007; Section Head: .

$<$ jrn $>$ Smith, L. E., \& Bisazza, J. A. (1982). The comprehensibility of three varieties of English for college students in seven countries. Language Learning, 32, 259-269.</jrn>

$<$ edb $>$ Solomon, B. B. (1991). Teaching an increasingly diverse undergraduate

population. In J. D. Nyquist, R. D. Abbott, D. H. Wulff, \& J. Sprague (Eds.), Preparing the professorate of tomorrow to teach (pp. 55-64). Dubuque, IA: Kendall Hunt. $</$ edb $>$

$<$ eref $>$ Takada, T. (2000, August/ September). The social status of L1 Japanese EFL teachers. TESOL Matters, 10(3). Retrieved November 7, 2007, from

http://www.tesol.org/s_tesol/sec_document.asp?CID=195\&DID=854</eref $>$

$<$ bok>Tanabe, Y. (2003). Korekara-no gattko eigo [School English from now].

Tokyo: Waseda University Press. $</$ bok $>$

$<$ jrn $>$ Tang, C. (1997). On the power and status of nonnative ESL teachers. TESOL

Quarterly, 31, 577-580.</jrn>

$<$ jrn>Tauroza, S., \& Luk, J. (1997). Accent and second language listening

comprehension. RELC Journal, 28, 54-71.</jrn>

$<$ jrn $>$ Varonis, E., \& Gass, S. (1982). The comprehensibility of non-native speech. Studies in Second Language Acquisition, 4, 114-136.</jrn>

$<$ jrn>Widdowson, H. G. (1994). The ownership of English. TESOL Quarterly, 28, $377-389 .</$ jrn $>$

$<$ jrn $>$ Wilcox, G. K. (1978). The effect of accent on listening comprehension: A Singapore study. English Language Teaching Journal, 32, 118-127.</jrn> 
Publisher: misc; Journal: tesol:TESOL Quarterly

Job\#: 154732; Volume: 41; Issue: 4; Art\#: 41-4-04; Prod\#: 41-4-04;

Month: December; Year: 2007; Section Head: .

$<$ eref $>$ Yang, G.-M. (2002, June 23). Ministries to hire 5,000 foreign language

teachers. The Chosun Ilbo. Retrieved March 15, 2004, from http://srch.chosun.com/cgi-

bin/english $</$ eref $>$

Page 35 of 40 
Publisher: misc; Journal: tesol:TESOL Quarterly

Job\#: 154732; Volume: 41; Issue: 4; Art\#: 41-4-04; Prod\#: 41-4-04;

Month: December; Year: 2007; Section Head: .

Table 1 Means and Standard Deviations for Eight Traits of Speakers of AmericanAccented English And Korean-Accented English (Based on a 7-Point Scale)

\begin{tabular}{|c|c|c|c|c|}
\hline & $\begin{array}{l}\text { American } \\
\text { English }\end{array}$ & $\begin{array}{l}\text { Korean } \\
\text { English }\end{array}$ & \multicolumn{2}{|c|}{$\begin{array}{l}\text { ANOVAs with repeated } \\
\text { measures }\end{array}$} \\
\hline & $\begin{array}{c}\text { Mean } \\
(S D)\end{array}$ & $\begin{array}{c}\text { Mean } \\
(S D)\end{array}$ & $F(1,296)$ & $\eta^{2}$ \\
\hline \multicolumn{5}{|l|}{ 2 Items for Ability to use English } \\
\hline $\begin{array}{l}\text { (1) Goodness of pronunciation } \\
(1=\text { poor, } 7 \text { = excellent })\end{array}$ & $\begin{array}{l}4.99 \\
(1.88)\end{array}$ & $\begin{array}{l}4.36 \\
(1.82)\end{array}$ & $23.01 * *$ & .07 \\
\hline $\begin{array}{l}\text { (2) Confidence in their use of English } \\
\text { (1= unconfident, } 7=\text { confident })\end{array}$ & $\begin{array}{l}5.10 \\
(1.70)\end{array}$ & $\begin{array}{l}4.51 \\
(1.76)\end{array}$ & $22.43 * *$ & .07 \\
\hline \multicolumn{5}{|l|}{3 Items for English teaching strategies } \\
\hline $\begin{array}{l}\text { (3) Focus on fluency vs. accuracy } \\
\text { (1= accuracy, } 7=\text { fluency) }\end{array}$ & $\begin{array}{l}4.28 \\
(1.68)\end{array}$ & $\begin{array}{l}3.83 \\
(1.78)\end{array}$ & 9.74* & .03 \\
\hline $\begin{array}{l}\text { (4) Use of Korean in classrooms } \\
\text { (1= Korean dominant, } 7=\text { English dominant })\end{array}$ & $\begin{array}{l}4.85 \\
(1.59)\end{array}$ & $\begin{array}{l}4.36 \\
(1.62)\end{array}$ & $17.43 * *$ & .06 \\
\hline $\begin{array}{l}\text { (5) Ability to explain the differences between } \\
\text { English and Korean } \\
(1=\text { excellent, } 7=\text { poor })\end{array}$ & $\begin{array}{l}3.81 \\
(1.68)\end{array}$ & $\begin{array}{l}3.77 \\
(1.71)\end{array}$ & .08 & \\
\hline \multicolumn{5}{|l|}{2 Items for General teaching strategies } \\
\hline $\begin{array}{l}\text { (6) Strictness } \\
(1=\text { strict, } 7=\text { casual })\end{array}$ & $\begin{array}{l}3.69 \\
(1.55)\end{array}$ & $\begin{array}{l}3.75 \\
(1.55)\end{array}$ & .08 & \\
\hline $\begin{array}{l}\text { (7) Empathy towards students' problems } \\
(1=\text { empathetic, } 7=\text { not empathetic })\end{array}$ & $\begin{array}{l}4.00 \\
(1.70)\end{array}$ & $\begin{array}{l}3.85 \\
(1.72)\end{array}$ & 1.63 & \\
\hline \multicolumn{5}{|l|}{1 Item for Teacher preference } \\
\hline $\begin{array}{l}\text { (8) Wish to have them as their English teacher } \\
(1=\text { not wish, } 7=\text { strongly wish) }\end{array}$ & $\begin{array}{l}4.33 \\
(2.07)\end{array}$ & $\begin{array}{l}3.76 \\
(1.97)\end{array}$ & $14.02 * *$ & .05 \\
\hline
\end{tabular}

Note. ${ }^{*} p<.005 .{ }^{* *} p<.0001$. 
Publisher: misc; Journal: tesol:TESOL Quarterly

Job\#: 154732; Volume: 41; Issue: 4; Art\#: 41-4-04; Prod\#: 41-4-04;

Month: December; Year: 2007; Section Head: .

Table 2 Students' Attitudes Toward the Two Teachers (Guises) by Comprehension Level

\begin{tabular}{|c|c|c|c|c|}
\hline & \multicolumn{2}{|c|}{$\begin{array}{c}\text { Comprehension low } \\
(n=155)\end{array}$} & \multicolumn{2}{|c|}{$\begin{array}{l}\text { Comprehension high } \\
(n=157)\end{array}$} \\
\hline & $\begin{array}{l}\text { American } \\
\text { English }\end{array}$ & $\begin{array}{l}\text { Korean } \\
\text { English }\end{array}$ & $\begin{array}{l}\text { American } \\
\text { English }\end{array}$ & $\begin{array}{l}\text { Korean } \\
\text { English }\end{array}$ \\
\hline \multicolumn{5}{|l|}{ 2 Items for Ability to use English } \\
\hline (1) Goodness of pronunciation & $\begin{array}{l}4.67 \\
(1.87)\end{array}$ & $\begin{array}{l}4.14 \\
(1.78)\end{array}$ & $\begin{array}{l}5.22 \\
(1.89)\end{array}$ & $\begin{array}{l}4.56 \\
(1.92)\end{array}$ \\
\hline (2) Confidence in their use of English & $\begin{array}{l}4.68 \\
(1.81)\end{array}$ & $\begin{array}{l}4.33 \\
(1.77)\end{array}$ & $\begin{array}{l}5.39 \\
(1.60)\end{array}$ & $\begin{array}{l}4.66 \\
(1.80)\end{array}$ \\
\hline \multicolumn{5}{|l|}{3 Items for English teaching strategies } \\
\hline (3) Focus on fluency vs. accuracy & $\begin{array}{l}4.02 \\
(1.53)\end{array}$ & $\begin{array}{l}4.08 \\
(1.70)\end{array}$ & $\begin{array}{l}4.51 \\
(1.80)\end{array}$ & $\begin{array}{l}3.57 \\
(1.89)\end{array}$ \\
\hline (4) Use of Korean in classrooms & $\begin{array}{l}4.80 \\
(1.68)\end{array}$ & $\begin{array}{l}4.21 \\
(1.67)\end{array}$ & $\begin{array}{l}4.94 \\
(1.51)\end{array}$ & $\begin{array}{l}4.49 \\
(1.61)\end{array}$ \\
\hline $\begin{array}{l}\text { (5) Ability to explain the differences between } \\
\text { English and Korean }\end{array}$ & $\begin{array}{l}4.13 \\
(1.75)\end{array}$ & $\begin{array}{l}3.95 \\
(1.77)\end{array}$ & $\begin{array}{l}3.57 \\
(1.60)\end{array}$ & $\begin{array}{l}3.61 \\
(1.69)\end{array}$ \\
\hline \multicolumn{5}{|l|}{2 Items for General teaching strategies } \\
\hline (6) Strictness & $\begin{array}{l}3.74 \\
(1.51)\end{array}$ & $\begin{array}{l}3.68 \\
(1.56)\end{array}$ & $\begin{array}{l}3.66 \\
(1.57)\end{array}$ & $\begin{array}{l}3.73 \\
(1.59) \\
\end{array}$ \\
\hline (7) Empathy towards students' problems & $\begin{array}{l}4.36 \\
(1.73)\end{array}$ & $\begin{array}{l}4.19 \\
(1.79)\end{array}$ & $\begin{array}{l}3.72 \\
(1.66)\end{array}$ & $\begin{array}{l}3.57 \\
(1.71)\end{array}$ \\
\hline (8) Wish to have them as their English teacher & $\begin{array}{l}3.95 \\
(2.10) \\
\end{array}$ & $\begin{array}{l}3.70 \\
(1.92)\end{array}$ & $\begin{array}{l}4.61 \\
(2.02)\end{array}$ & $\begin{array}{l}3.77 \\
(2.07) \\
\end{array}$ \\
\hline
\end{tabular}

Note. For each cell, the first value indicates students' mean responses and the value enclosed in parentheses indicates the standard deviation. 
Publisher: misc; Journal: tesol:TESOL Quarterly

Job\#: 154732; Volume: 41; Issue: 4; Art\#: 41-4-04; Prod\#: 41-4-04;

Month: December; Year: 2007; Section Head: .

Table 3 Students' Attitudes Toward the Two Teachers (Guises) Based on Their Experience of Learning English From Native English Speakers

\begin{tabular}{|c|c|c|c|c|}
\hline & \multicolumn{2}{|c|}{$\begin{array}{l}\text { Students who had not } \\
\text { been taught by native } \\
\text { English speakers } \\
(n=116)\end{array}$} & \multicolumn{2}{|c|}{$\begin{array}{c}\text { Students who had been } \\
\text { taught by native English } \\
\text { speakers } \\
(n=171)\end{array}$} \\
\hline & $\begin{array}{l}\text { American } \\
\text { English }\end{array}$ & $\begin{array}{l}\text { Korean } \\
\text { English }\end{array}$ & $\begin{array}{c}\text { American } \\
\text { English }\end{array}$ & $\begin{array}{l}\text { Korean } \\
\text { English } \\
\end{array}$ \\
\hline \multicolumn{5}{|l|}{2 Items for Ability to use English } \\
\hline (1) Goodness of pronunciation & $\begin{array}{l}4.93 \\
(1.80)\end{array}$ & $\begin{array}{l}4.48 \\
(1.73)\end{array}$ & $\begin{array}{l}4.97 \\
(1.98) \\
\end{array}$ & $\begin{array}{l}4.28 \\
(1.96)\end{array}$ \\
\hline (2) Confidence in their use of English & $\begin{array}{l}4.98 \\
(1.73)\end{array}$ & $\begin{array}{l}4.59 \\
(1.81)\end{array}$ & $\begin{array}{l}5.15 \\
(1.73)\end{array}$ & $\begin{array}{l}4.50 \\
(1.80)\end{array}$ \\
\hline \multicolumn{5}{|l|}{3 Items for English teaching strategies } \\
\hline (3) Focus on fluency vs. accuracy & $\begin{array}{l}4.08 \\
(1.63)\end{array}$ & $\begin{array}{l}3.71 \\
(1.80)\end{array}$ & $\begin{array}{l}4.41 \\
(1.72)\end{array}$ & $\begin{array}{l}3.92 \\
(1.85) \\
\end{array}$ \\
\hline (4) Use of Korean in classrooms & $\begin{array}{l}5.04 \\
(1.44)\end{array}$ & $\begin{array}{l}4.44 \\
(1.60)\end{array}$ & $\begin{array}{l}4.82 \\
(1.70)\end{array}$ & $\begin{array}{l}4.32 \\
(1.68)\end{array}$ \\
\hline $\begin{array}{l}\text { (5) Ability to explain the differences between } \\
\text { English and Korean }\end{array}$ & $\begin{array}{l}4.05 \\
(1.61)\end{array}$ & $\begin{array}{l}3.87 \\
(1.82)\end{array}$ & $\begin{array}{l}3.72 \\
(1.73)\end{array}$ & $\begin{array}{l}3.71 \\
(1.68)\end{array}$ \\
\hline \multicolumn{5}{|l|}{2 Items for General teaching strategies } \\
\hline (6) Strictness & $\begin{array}{l}3.70 \\
(1.66)\end{array}$ & $\begin{array}{l}3.63 \\
(1.54)\end{array}$ & $\begin{array}{l}3.75 \\
(1.49)\end{array}$ & $\begin{array}{l}3.75 \\
(1.61)\end{array}$ \\
\hline (7) Empathy toward students' problems & $\begin{array}{l}4.24 \\
(1.61)\end{array}$ & $\begin{array}{l}3.91 \\
(1.71)\end{array}$ & $\begin{array}{l}3.87 \\
(1.78)\end{array}$ & $\begin{array}{l}3.81 \\
(1.81)\end{array}$ \\
\hline \multicolumn{5}{|l|}{1 Item for Teacher preference } \\
\hline (8) Wish to have them as their English teacher & $\begin{array}{l}4.16 \\
(1.89)\end{array}$ & $\begin{array}{l}3.81 \\
(2.01)\end{array}$ & $\begin{array}{l}4.46 \\
(2.17)\end{array}$ & $\begin{array}{l}3.73 \\
(2.02)\end{array}$ \\
\hline
\end{tabular}


Publisher: misc; Journal: tesol:TESOL Quarterly

Job\#: 154732; Volume: 41; Issue: 4; Art\#: 41-4-04; Prod\#: 41-4-04;

Month: December; Year: 2007; Section Head: .

Table 4 Students' Attitudes Toward the Two English Teachers (Guises) by Region

\begin{tabular}{|c|c|c|c|c|}
\hline & \multicolumn{2}{|c|}{ Seoul $(n=173)$} & \multicolumn{2}{|c|}{ Daegu $(n=139)$} \\
\hline & $\begin{array}{l}\text { American } \\
\text { English }\end{array}$ & $\begin{array}{l}\text { Korean } \\
\text { English }\end{array}$ & $\begin{array}{l}\text { American } \\
\text { English }\end{array}$ & $\begin{array}{l}\text { Korean } \\
\text { English }\end{array}$ \\
\hline \multicolumn{5}{|l|}{2 Items for Ability to use English } \\
\hline (1) Goodness of pronunciation & $\begin{array}{l}4.82 \\
(1.96)\end{array}$ & $\begin{array}{l}4.37 \\
(1.95)\end{array}$ & $\begin{array}{l}5.15 \\
(1.81)\end{array}$ & $\begin{array}{l}4.36 \\
(1.75)\end{array}$ \\
\hline (2) Confidence in their use of English & $\begin{array}{l}5.03 \\
(1.70)\end{array}$ & $\begin{array}{l}4.51 \\
(1.82)\end{array}$ & $\begin{array}{l}5.09 \\
(1.77)\end{array}$ & $\begin{array}{l}4.50 \\
(1.75)\end{array}$ \\
\hline \multicolumn{5}{|l|}{3 Items for English teaching strategies } \\
\hline (3) Focus on fluency vs. accuracy & $\begin{array}{l}4.34 \\
(1.70)\end{array}$ & $\begin{array}{ll}3.81 \\
(1.85)\end{array}$ & $\begin{array}{l}4.21 \\
(1.69)\end{array}$ & $\begin{array}{l}3.81 \\
(1.79)\end{array}$ \\
\hline (4) Use of Korean in classrooms & $\begin{array}{l}4.74 \\
(1.61)\end{array}$ & $\begin{array}{l}4.47 \\
(1.71)\end{array}$ & $\begin{array}{l}5.04 \\
(1.55)\end{array}$ & $\begin{array}{l}4.22 \\
(1.55)\end{array}$ \\
\hline $\begin{array}{l}\text { (5) Ability to explain the differences between English } \\
\text { and Korean }\end{array}$ & $\begin{array}{l}3.81 \\
(1.80)\end{array}$ & $\begin{array}{l}3.87 \\
(1.82)\end{array}$ & $\begin{array}{l}3.87 \\
(1.55)\end{array}$ & $\begin{array}{l}3.64 \\
(1.62)\end{array}$ \\
\hline \multicolumn{5}{|l|}{ 2 Items for General teaching strategies } \\
\hline (6) Strictness & $\begin{array}{l}3.49 \\
(1.56)\end{array}$ & $\begin{array}{l}3.82 \\
(1.62)\end{array}$ & $\begin{array}{l}3.96 \\
(1.49)\end{array}$ & $\begin{array}{l}3.55 \\
(1.49)\end{array}$ \\
\hline (7) Empathy towards students' problems & $\begin{array}{l}3.88 \\
(1.78) \\
\end{array}$ & $\begin{array}{l}3.86 \\
(1.80) \\
\end{array}$ & $\begin{array}{l}4.19 \\
(1.63) \\
\end{array}$ & $\begin{array}{l}3.85 \\
(1.74) \\
\end{array}$ \\
\hline \multicolumn{5}{|l|}{1 Item for Teacher preference } \\
\hline (8) Wish to have them as their English teacher & $\begin{array}{l}4.39 \\
(2.15)\end{array}$ & $\begin{array}{l}3.72 \\
(2.10)\end{array}$ & $\begin{array}{l}4.19 \\
(2.00)\end{array}$ & $\begin{array}{l}3.77 \\
(1.86)\end{array}$ \\
\hline
\end{tabular}


Publisher: misc; Journal: tesol:TESOL Quarterly

Job\#: 154732; Volume: 41; Issue: 4; Art\#: 41-4-04; Prod\#: 41-4-04;

Month: December; Year: 2007; Section Head: .

Table 5 Correlations of Attitudinal Factors With Students' Preferences for Having One or the Other Teacher as Their English Teacher (Pearson Correlation Coefficients)

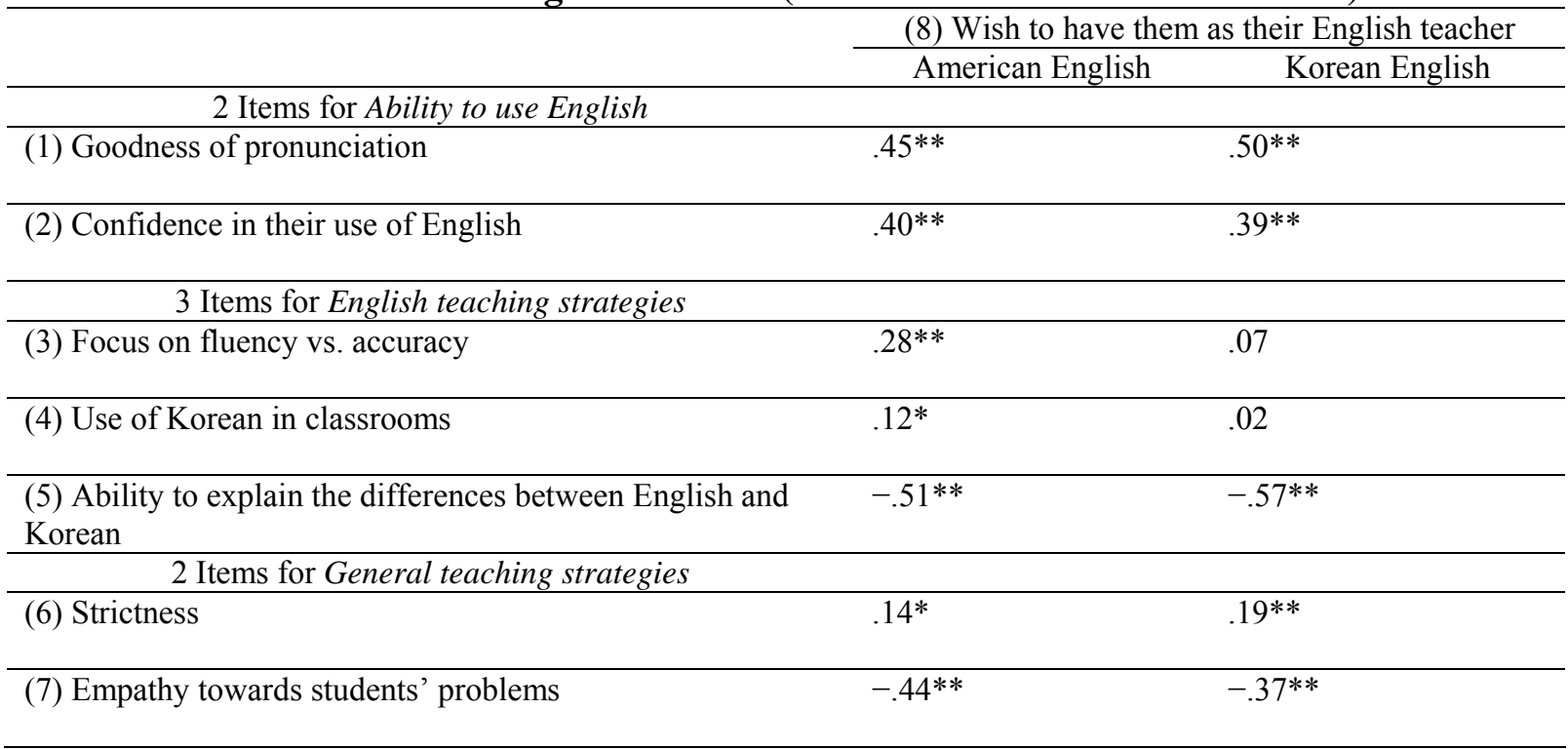

Note. $* p<.05 . * * p<.01$.

\footnotetext{
${ }^{1}$ In addition to the two accented versions of the oral texts prepared for this study, the judges also listened to two more recordings created using different speakers as distracters.

${ }^{2}$ Before employing the ANOVA with repeated measures, the sphericity assumption was tested for the attitude factor. (Since the accent factor has only two levels, the sphericity assumption for this factor is always met.) Epsilon was examined to test the assumption (Baguley, 2003). Epsilon (Greenhouse-Geisser) was .55; the sphericity was violated. As such, the GreenhouseGeisser correction was employed in the subsequent analyses (the degrees of freedom were adjusted in the ANOVA analyses).

${ }^{3}$ The eta-squared values were small here. However, Cohen (1988) sated that classical eta-squared values typically range from .01 to .09 in the social science, so the results of the present study may not be untypical.

${ }^{4}$ The alpha level was adjusted based on the Bonferroni multiple comparison method (a set alpha level was .05). An adjusted alpha $(\alpha=.006)$ was employed in order to reduce the risk of getting false positives. The same adjusted alpha levels were used in each of the analyses that follow.
} 